\title{
1st Transylvanian International Film Festival in Cluj, Romania
}

\author{
By Ron Holloway
}

\section{Fall 2002 Issue of KINEMA}

Other first film festivals should have it so good. Every guest arriving from abroad to attend the First Transylvanian International Film Festival (3-9 June 2002) in the Romanian city of Cluj (formerly Klausenburg) asked the same question: "Where's Dracula's castle, and how can I get there?" To which Tudor Giurgiu, the festival's founder-director, responded with an same amused grin: "Stay around until closing night: we're screening Murnau's Nosferatu to musical accompaniment!" Just another way of saying that no less than four castles lay claim to Dracula's hideout. "Probably Bram Stoker meant the castle in Sighisoara (formerly Sch $\tilde{A}$ ossburg)," said one informed source. "Sch $\tilde{A}$ ossburg is a 13th-century museum town, only an hour's drive away."

Forget Dracula's castle on your first visit to Cluj-Napoca, inhabited by the Dacians in ancient times and founded by the Romans in the 2nd century. The city with the most moviegoers in Romania, Cluj (formerly part of Austria-Hungary) has academies and universities, baroque architecture and gothic churches, four bishoprics, a national theatre and opera house, museums and cultural centres for Hungarian and German minorities. Some student-volunteers at the festival spoke five languages: Romanian, English, French, German, and Hungarian. The 108-page CIFF catalogue boasted government and city support, two dozen sponsors (Nescafe, Kodak), and key international film partners (Wild Bunch, European Film Academy). Last, but certainly not least, Tudor Giurgiu is surrounded by cineastes, among them artistic programmer Mihai Chirilov and media professional Ada Roseti.

Altogether, 45 films were programmed in two venues. The competition, opened to first and second features, ran the full spectrum from a studio film (Michael Gondry's Human Nature, USA /France) to an amateur production costing a mere \$1,000 (Grzegorz Lipiec's That Life Has Meaning, Poland). Oana Pellea, Romania's popular stage-and-screen actress, served on the jury. Among the international award-winners in the "SuperNova" section were Danis Tanovic's No Man's Land (Bosnia), David Lynch's Mulholland Drive (USA), Ulrich Seidl's Dog Days (Austria), Hayao Miyazaki's animated feature Spirited Away (Japan), Lukas Moodysson's Together (Sweden), Sean Penn's The Pledge (USA), Pavel Lungin's The Wedding (Russia) und BÃ@la Tarr's Werckmeister Harmoniak (Hungary). No Man's Land, awarded this year's Oscar for Best Foreign Film, was voted the Audience Prize in Cluj.

British director Michael Radford arrived for a special screening of his Dancing at the Blue Iguana. Jason Priestley, Canadian actor and popular TV personality (Beverly Hills), particularly in Romania, was the surprise visitor for the screening of Richard Kwietniowski's Love and Death on Long Island (UK, 1997), in which Priestley gives a finely sketched performance as the object of John Hurt's plaintive desire. The "3 x 3" retrospective saluted Francois Ozon (France), Michael Haneke (Austria), and Radu Gabrea (Romania /Germany), each with a trio of films.

One film in the Romanian Cinema section drew a packed house: Lucien Pintille's The Afternoon of a Torturer, a open-ended, part-fact, part-fiction dialogue with a former member of the dreaded Securitate during the Ceaucescu dictatorship. Another festival highlight was "Shadows," a series of horror and fantasy films that included Bill Plympton's Mutant Aliens (USA), Jan Å vankmajer's Otes ̃̃jek (Czech Republic), Takashi Miike's Audition und Mamoru Oshii's Avalon (Japan). Last, but not least, the "Transit" program featured shorts and documentaries by film students.

Cristian Mungiu's Occident (Romania) was awarded the Transylvanian Trophy, the festival's main prize. A tragicomedy about the longing of many Romanians to emigrate to the West -- thus the title -- Occident reworks the theme by weaving three consecutive stories together within the period of a week to portray the same events from entirely different perspectives. Similarly, in Andrea Sedlä¡kovÃ j's Victims and Murders (Czech Republic), the incestuous love of half-siblings is recounted in flashbacks to throw light on the tragic events of the present. The film's ensemble -- Ivana Ch $\tilde{A}^{1} \frac{1}{2} 1 \mathrm{kov} \widetilde{A}_{i}$ and Karel Roden as grownups, Monika Hillmarov $\tilde{A}_{i}$ and Vladim $\tilde{A r} \AA$ kult $\tilde{A} @$ ty as youths -- were jointly awarded the Prize for Best Actors. 
And the Film Camera Award went to AndrÃ is Nagy for his atmospheric cinematography on Andr $\tilde{A}_{i s}$ Fesos's Seashore, Dusk (Hungary). It's the story of a single young Hungarian mother isolated on the German island of RÃ $\tilde{A}^{1 / 4 g e n}$ on the Baltic Sea coast, who makes the acquaintance of a blind man in Budapest via a mistaken telephone-sex call, gradually becomes enamoured by his story-telling, and doesn't discover his fate until the very end of the film although clues are given all along the way. Filmed in winter, the elements of sea and wind, a dreary sky and a dismal dusk, convey a feeling of longing for warmth and an unrequited love.

The discoveries of the festival? Two classics by Radu Gabrea: Two Little for a Big War (1969) and Beyond the Sands (1973), both poetic and as important today as when they were produced three decades ago. Two Little for a Big War, an antiwar film, made it as far as the Locarno film festival. Beyond the Sands, a metaphorical statement on socialism, was immediately banned by Ceaucescu personally. Shortly thereafter, Gabrea emigrated to Germany. Returning to Romania at the end of the 1990s, he was one of those chiefly responsible for the passing of a new film law that, in turn, is instrumental in subsidizing the shorts, documentaries and feature films of a new generation of Romanian filmmakers.

\section{Author Information}

Ron HOLLOWAY (1933-2009) was an American critic, film historian, filmmaker and correspondent who adopted Europe as his home in the early fifties and spent much of his life in Berlin. He was an expert on the study of German cinema and against all odds produced, with his wife Dorothea, the journal German Film, keeping us up-to-date with the work of directors, producers and writers and the showing of German films around the world.

In 2007, Ron Holloway and his wife were awarded the Berlinale Camera Award. Ron also received the Bundesverdienstkreuz (German Cross of Merit), Polish Rings, Cannes Gold Medaille, the American Cinema Foundation Award, the Diploma for Support of Russian Cinema and an honorary award from the German Film Critics' Association.

Ron was also a valued contributor to Kinema for the past fifteen years. 